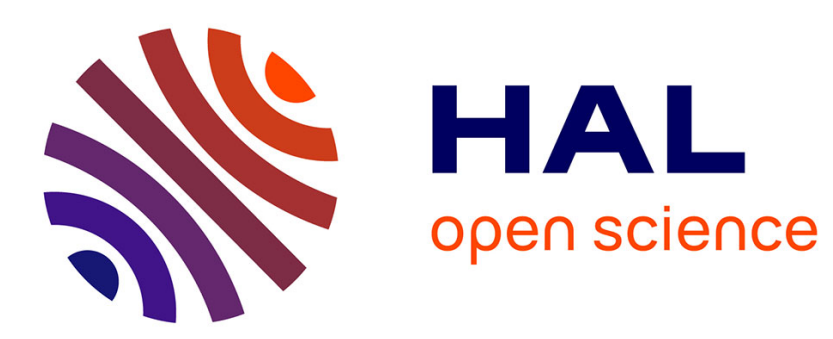

\title{
Alevi Communities in Western Europe: Identity and Religious Strategies
}

\author{
Elise Massicard
}

\section{To cite this version:}

Elise Massicard. Alevi Communities in Western Europe: Identity and Religious Strategies. Yearbook of Muslims in Europe, Brill, p. 561-592, 2010, 9789004184756. halshs-00801075

\section{HAL Id: halshs-00801075 https://shs.hal.science/halshs-00801075}

Submitted on 8 Mar 2017

HAL is a multi-disciplinary open access archive for the deposit and dissemination of scientific research documents, whether they are published or not. The documents may come from teaching and research institutions in France or abroad, or from public or private research centers.
L'archive ouverte pluridisciplinaire HAL, est destinée au dépôt et à la diffusion de documents scientifiques de niveau recherche, publiés ou non, émanant des établissements d'enseignement et de recherche français ou étrangers, des laboratoires publics ou privés. 


\title{
Alevi communities in Western Europe: identity and religious strategies
}

\author{
Elise Massicard ${ }^{1}$
}

In: Yearbook of Muslims in Europe, Brill, Leiden, 2010, pp. 561-592.

\section{INTRODUCTION}

Aleviness $^{2}$ has become a Western European phenomenon. Today, Alevi organisations exist in Austria, Belgium, ${ }^{3}$ Denmark, France, Great-Britain, Italy, the Netherlands, Norway, Sweden and Switzerland - not to mention Australia, Canada and the United States. Although most Alevis settled in Western European countries in the 1960s, 1970s and early 1980s, Aleviness has only recently appeared in the public spheres of settlement countries, indicating that this trend is due not so much to the migration process itself, as to the growing public awareness of questions regarding Islam. Another important factor has been a general Alevi resurgence, observed both in Turkey and in the settlement countries since the late $1980 \mathrm{~s} .{ }^{4}$ This development leads me to distinguish between the terms Aleviness, to refer to the social fact, and Alevism, to refer to activism in the name of Aleviness, 'Alevi' and 'Alevist' being used to refer to the adherents of 'Aleviness' and 'Alevism' respectively.

The aim of this article is to provide an overview of the Alevi phenomenon in Western Europe. Since most Alevis in Europe live in Germany, and since most studies on Alevis in Europe deal with the situation there, Germany will inevitably dominate the article. The first part analyses the settlement of Alevis in Western European countries and the main trends and

\footnotetext{
${ }^{1}$ Tenured research fellow in sociology, Centre National de la Recherche Scientifique, Paris, France

${ }^{2}$ For an overview of Aleviness see Kehl-Bodrogi, Krisztina, Die Kızllbaş/Aleviten: Untersuchungen über eine esoterische Glaubensgemeinschaft in Anatolien (Berlin, Klaus Schwarz, 1995).

${ }^{3}$ On Alevis in Belgium see Lebrecht, Michaël, Alévis en Belgique: Approche générale et étude de cas, Sybidi Papers 21 (Louvain-la-Neuve: Academia Bruylant, 1997.

${ }^{4}$ On this movement see Massicard, Elise, L'autre Turquie: Le mouvement aléviste et ses territoires (Paris, Presses Universitaires de France, 2005).
} 
dynamics of the revival since the late 1980s. The second part studies the ways in which Alevist organisations' strategies for institutionalization and recognition differ in the various places where they have settled, these strategies being strongly linked to the opportunities available. As a result, divergent identities are claimed in different places. The last part deals with the difficulties of transnationalising identity and recognition strategies on various scales, including the European scale.

\section{THE SETTLEMENT OF ALEVIS IN WESTERN EUROPE: FROM INVISIBILITY TO REVIVAL}

\subsection{Settlement in Western Europe}

When and how have Alevis settled in Western Europe? The key periods of migration from Turkey are about the same for all European countries; three main phases can be distinguished. First, Alevi men began migrating in large numbers to West European countries overwhelmingly to West Germany - in the 1960s, in the context of the demand for migrant labour from Turkey, among other countries. A second phase began with the official ending of labour migration in the early 1970s. Paradoxically, this resulted in an increase in the numbers of migrants from Turkey, especially of women and children coming for family reunion. The third phase was in the years immediately before and after the 1980 military coup in Turkey and saw the greatest influx of Turks into Europe since the end of labour migration, many of them coming as asylum seekers. This politically-motivated emigration mainly involved leftists, among whom Alevis were probably overrepresented.

Since no country - neither Turkey nor any of the settlement countries - has official statistics that use 'Alevi' as a category of belonging, it is hard to know how many Alevis have migrated to Europe. Some qualitative data suggest that Alevis have had a stronger tendency than their Sunni counterparts to engage in international migration because of the repression to 
which they have been subjected ${ }^{5}$, because of their economic and social marginalisation, and because they may have been better able to forge community-wide migration networks. ${ }^{6}$

However, no statistical source has ever confirmed this hypothesis. A study on a sub-province near the Black Sea in fact indicates a slower growth rate of the population of Alevi villages compared with that of Sunni villages, indicating a higher outmigration rate for Alevis. Unfortunately, it does not distinguish internal from international migration. ${ }^{7}$ Another study conducted on a sub-province in Central Anatolia tends to show that migration from Alevi villages is not greater than from Sunni villages, but again this study does differentiate between migrants who settle in Turkish cities and those who go abroad. ${ }^{8}$ It is therefore difficult to draw general conclusions. Today, observers estimate the number of Alevis living in Germany at between 400,000 and 600,000. ${ }^{9}$ More precise studies show that they do not withdraw into ghettos, but that they live scattered in different places. ${ }^{10}$

\subsection{An invisible group}

An important characteristic of Alevis settling in Western European countries is that they initially remained invisible. Alevis did not establish a formalised religious life in the settlement countries, unlike Sunnis, who re-created their own religious institutions quite

\footnotetext{
${ }^{5}$ Mandel, Ruth, “The Alevi-Bektashi identity in a foreign context: the example of Berlin”, in A.Popovic and G.Veinstein (eds), "L'ordre mystique des Bektachis et les groupes relevant de Hadji Bektach", Revue des Etudes Islamiques, vol.60, no.1, 1992, pp.419-426 (423); Mandel, Ruth, "Shifting centres and emergent identities: Turkey and Germany in the lives of Turkish Gastarbeiter", in D.Eickelman and J.Piscatori (eds), Muslim Travellers: Pilgrimage, Migration, and the Religious Imagination (London: Routledge, 1990), pp.153-171 (165). ${ }^{6}$ Faist, Thomas, The Volume and Dynamics of International Migration and Transnational Social Spaces (New York: Oxford University Press, 2000), p.135.

${ }^{7}$ Shankland, David, The Alevis in Turkey: The Emergence of a Secular Islamic Tradition (London: Routledge Curzon, 2003), pp.45f.

${ }^{8}$ Fliche, Benoit, Odyssées turques: Les migrations d'un village anatolien (Paris: CNRS Editions, 2007), pp.46, 56-57.

${ }^{9}$ Sökefeld, Martin, "Einleitung: Aleviten in Deutschland - von takiye zur Alevitischen Bewegung”, in M.Sökefeld (ed.), Aleviten in Deutschland: Identitätsprozesse einer Religionsgemeinschaft in der Diaspora (Bielefeld: Transkript, 2008), pp.7-36 (32).

${ }^{10}$ Shankland, David and Atila Çetin, "Aleviten in Deutschland", in M.Sökefeld (ed.), Aleviten in Deutschland: Identitätsprozesse einer Religionsgemeinschaft in der Diaspora (Bielefeld: Transkript, 2008), pp.219-239 (224).
} 
quickly. In Turkey, Alevis had a formalised religious life, even if it was invisible to the public because of its illegality. Why, then, was it not 'exported' to the settlement countries? The first reason is that at the time of emigration, Alevi religious practice was declining in Turkey itself. This was partly due to the growing politicisation of Alevis on the left since the 1960s. In many villages, religious leaders, the dedes, were rejected by the younger generation as exploiters of the people, and ceremonies could no longer be held. ${ }^{11}$ Those who emigrated as refugees because of their leftist activism would definitely not try to foster religious practice in their settlement countries. Another factor behind the decline of religious practice was migration itself. The areas where settlement took place - be they Turkish or European cities were cut off from the village community contexts that traditionally provided the framework for Alevi religious practice. The performance of a religious ceremony was linked not so much to precise dates as to the presence of the religious leader and of the community, which was made difficult by migration. Nevertheless, it would be an exaggeration to argue that Alevi religious life disappeared completely in settlement countries. Many witnesses report that in the 1970s and 1980s, especially among migrant workers, private gatherings of relatives, fellow villagers and friends were organised, where Alevi songs were sung. Some dedes also visited their followers (talips) in Europe, and sometimes religious ceremonies were performed within restricted groups, but this was a limited phenomenon.

A second reason for the invisibility of Alevi migrants in their settlement countries is that many of them continued to practise 'dissimulation' (takiye), i.e. to hide or deny their identity in public, as they had previously done in Turkey. Dissimulation is a strategy legitimised in Shi'a Islam as a defensive response to persecution. Some parents even hid their Alevi identity from their children in order to prevent them from suffering prejudice or

\footnotetext{
${ }^{11}$ For this point see Massicard, Elise, “Alevism in the 1960s: social change and mobilisation” in H.Markussen (ed.), Alevis and Alevism: Transformed Identities (Istanbul: Isis, 2005), pp.109-135 (113f).
} 
exclusion by Sunni children. ${ }^{12}$ Alevi immigrants were known to be Alevis only within limited circles, through their village of origin ${ }^{13}$ or because they had mostly come to Europe via chain migration. Since nobody declared himself publicly to be Alevi, Sunni Islam was the only visible religion of migrants from Turkey. In the host societies, Turkish migrants were therefore considered to be religiously homogeneous, which was congruent with Turkey's official identity and discourse.

Finally, Alevis in Europe did not at first organise explicitly as Alevis. They did not initially claim any distinctiveness, since they basically came either to work or for political reasons, and thought they were in Europe only temporarily. As in Turkey, most Alevis who took up commitments beyond their daily life engaged in leftist political groups or labour unions. In the late 1970s and early 1980s, in Turkey as in the Turkish diaspora, large numbers of Alevis were involved in many leftist organizations, but Aleviness played no explicit role since these individuals were Marxists and atheists.

Alevi organisations increasingly became autonomous from the left during the 1970s. The first Alevi organisation was created in Southern Germany in the 1970s. ${ }^{14}$ Its full name Türkiye Aleviler Birliği, Union of Alevis of Turkey - was never used in public and its acronym, TALEB, only implicitly recalled the Alevi term talip. As a consequence, only insiders were aware that this was in fact an Alevi organisation. When it was officially registered, later in the 1970s, the organisation was renamed to the more neutral Türkiye Amele Birliği (Workers Union of Turkey), so that it was outwardly a workers' organisation, although it functioned in close collaboration with the Alevi leftist party in Turkey, the Union Party of

\footnotetext{
${ }^{12}$ Henrich, Beatrice, "Alevitische Geschichte erinnern - in Deutschland”, in M.Sökefeld (ed.), Aleviten in Deutschland: Identitätsprozesse einer Religionsgemeinschaft in der Diaspora (Bielefeld: Transkript, 2008), pp.37-64 (55).

${ }^{13}$ Naess, Ragnar, "Being an Alevi Muslim in South-Western Anatolia and in Norway: the impact of migration on a heterodox Turkish community", in T.Gerholm and Y.G.Lithman (eds), The New Islamic Presence in Western Europe (London: Mansell, 1988), pp.174-195 (187ff.).

${ }^{14}$ Later than in Turkey, where a few Alevi organisations had been created in the 1960s.
} 
Turkey (Türkiye Birlik Partisi, TBP) founded in $1966 .{ }^{15}$ It gathered together more than 30 local organizations, which were strongly related to leftist groups.

A further step towards autonomy was linked to escalating political violence in Turkey. In the late 1970s, the nationalist and religious right-wing organised several attacks on leftists and Alevis in Central Anatolian cities, of which the bloodiest one took place in Kahramanmaraş in December 1978, when a leftist party strongly supported by Alevis, the Cumhuriyet Halk Partisi (CHP, Republican People's Party), was in government. Alevi members of the CHP in exile wanted to protest against the government, but the party headquarters rejected their demands. As a consequence, many Alevi supporters left the party and, together with activists from the TBP in exile, founded the Union of Patriots (Yurtseverler Birliği, YSB) in 1979. A few months later, it became a federation. Again, this name gave no hint of Aleviness, and the YSB began as a political organisation. However, it also engaged in religious and cultural activities and organised the first public Alevi religious ceremonies in Germany. After the military coup in Turkey in 1980, its membership rapidly decreased because many supporters feared that they or their families in Turkey would be persecuted. The federation was dissolved in 1983, but some of its biggest associations continued functioning. ${ }^{16}$

The first explicitly Alevi organisations in Western Europe were created in the 1980s, when a general Alevi revival was taking place. In Germany, the first associations with names that indicated their Aleviness (named, for example, after the Alevi saint Hacı Bektaş Veli) appeared in the late 1980s. Seven of them joined forces in 1991 and formed the Federation of Alevi Communities. The first Swiss Alevi association was founded in 1992 in Basel, and the

\footnotetext{
15 Şener, Cemal and Miyase İlknur, Alevilik ve Şeriat (Istanbul: Ant, 1995), pp.115-116.

${ }^{16}$ Sökefeld, Martin, Struggling for Recognition: The Alevi Movement in Germany and in Transnational Space (New York/London, Berghahn, 2008), pp.48ff.
} 
Alevi Cultural Centre and Cemevi of England (Inglitere Alevi Kültür Merkezi ve Cemevi) was created in 1993 in London.

\section{THE ALEVI RESURGENCE IN EUROPE}

The Alevi revival was linked to global developments, to developments taking place in Turkey, but also in the conditions of Alevis living in Western European countries. Among general factors, the overall decline of the left, to which many Alevis were committed, was crucial. This decline was reinforced in Turkey by the 1980 military coup, which made revolutionary aims unattainable. At the same time, new ideologies, especially of identity and ethnicity, gained prominence. This was also the case in Turkey, especially in relation to the Kurdish issue, with the guerrilla war started by the PKK (Partiya Karkeren Kurdistan, Kurdish Workers' Party) at the beginning of the 1980s. The Kurdish question affected Alevis because many of them were also Kurds, and because it questioned Turkish national identity and brought the struggle for other specific identities to the fore. Another factor was that, after the 1980 military coup, the junta re-oriented Turkish national ideology by stressing Sunni Islam as a means to overcome the political polarisation experienced in the 1970s and to enforce national unity. Consequently, Sunni religious instruction was made compulsory in Turkish schools and many Alevis perceived these developments as attempts at assimilation. Furthermore, political Islam was gaining momentum in Turkey, which many Alevis considered a threat and, finally, two events accelerated the Alevi revival. In July 1993, an Alevi leftist association organised a cultural festival in the conservative Central Anatolian city of Sivas, in which many prominent leftist intellectuals and artists participated. A large group of violent right-wing (both Islamist and nationalist) demonstrators targeted the festival and set fire to the hotel hosting the participants. Thirty-seven of them died, while the security forces 
remained indifferent. The second event occurred in March 1995: following an attack on an Alevi café in the Gazi neighborhood in Istanbul, clashes between demonstrators and the police ended in the death of fifteen demonstrators. Both events were broadly interpreted as attacks against Alevis and accelerated the revival: many Alevis in both Turkey and Western Europe started to assert their Aleviness, and many Alevi organisations were founded.

In addition, there were other relevant factors specific to the settlement contexts. First, many Alevi migrants in Europe had identified themselves as Turkish but, after these violent events, Turkishness no longer provided a refuge for them and many of them shifted their identification towards Aleviness. ${ }^{17}$ Second, the arrival of women and children led to increased social pressures. In the late 1980s, in some French towns, although Turkish migrants had previously socialised together across religious orientations, divisions between Sunnis and Alevis became more prominent. ${ }^{18}$ In various places, Alevis began to create their own organisations (such as village associations), independent of general Turkish associations. ${ }^{19}$ Third, many migrants came to realise that their presence in Western Europe was not going to be short-lived, and they re-oriented their commitments to the place they lived in. In this context, come policies in settlement countries both fostered and gave direction to an Alevi revival.

\subsection{Multiculturalism and the cultural framing of Aleviness}

The Alevi revival was particularly fostered by policies of multiculturalism. In the 1980s, and even more so in the 1990s, multiculturalism gained momentum in countries such as Great Britain, Germany, the Netherlands and Sweden, although this was less the case in other

\footnotetext{
${ }^{17}$ Kaya, Ayhan, "Multicultural clientelism and Alevi resurgence in the Turkish diaspora: Berlin Alevis", New Perspectives on Turkey, vol.18 (Spring 1998), pp.23-49 (38-39).

${ }^{18}$ Fliche, Odyssées turques, pp. 120-121.

${ }^{19}$ Naess, "Being an Alevi Muslim", pp.187ff.
} 
countries, such as France. The former countries began to treat the issue of immigration mainly in terms of cultural difference, promoting the idea of a right to difference and its 'free expression', and implementing policies based on discourses of identity and culture. ${ }^{20}$ Multicultural policies served as a new way of public incorporation and provided many institutional opportunities, resources and space for the formalisation of 'cultural' organisations. By making culture the main arena for the recognition, participation and struggle of migrants, they shaped the institutional and discursive framework for migrants' claim-making. Multiculturalism also provided Aleviness with its first opportunity for public visibility in the German public space. After Turks and Kurds, the heightened awareness of questions concerning cultural identity was also applied to Alevis. Perceiving this opportunity, Alevists began to stress their distinctiveness from 'Turkish culture' as a strategy to negotiate with the majority society for subsidies or integration, and they framed Aleviness in terms of a culture in need of protection. ${ }^{21}$

Until then, Aleviness, unlike Sunnism, was not recognised as a component of the identity of Turkish migrants. It was only in the 1990s that the German authorities came to recognise this distinction, and they began conceiving of Aleviness mainly in these cultural terms. During the 'Alevi Cultural Night' organised by the biggest Alevi organisation in Berlin in 1996, the Commissioner for Foreigners' Affairs emphasised the pluralist structure of the city, using a culturalist discourse, and declared her support for Alevis to express their cultural identity in the public space. ${ }^{22}$

This cultural opportunity thus had important consequences for the way in which Alevi organisations appeared and developed in Europe. The first Alevi organisations in Germany

\footnotetext{
${ }^{20}$ For the Berlin case, see Vertovec, Steven, "Berlin Multikulti: Germany, 'foreigners' and 'world-openness"”, New Community, vol.22, no.3 (July 1996), pp.381-399.

${ }^{21}$ Kaya, "Multicultural clientelism", pp.39ff.

${ }^{22}$ Kaya, "Multicultural clientelism", pp.42-43.
} 
were quite inward-looking and were hardly in contact with German institutions and the public, their main purpose being to meet the spiritual needs of their local communities. In 1989, however, another, more outward-looking initiative took place: in Hamburg, former leftists created an informal group, the 'Alevi culture group'. It aimed to campaign for the public recognition of Aleviness, and organised the first explicitly Alevi public event, an 'Alevi Culture Week', supported financially by German multicultural institutions. After the success of this event, the group created an 'Alevi Cultural Centre', and similar centres were created in other German cities. In 1993, the Sivas events put the unification of all Alevi organisations onto the agenda, and the inward-looking associations and the 'cultural centres' competed for the leadership of the movement. In the end, the cultural centres gained prominence, because they were more numerous, but also because of the political experience of their members, which enabled them to organise mass demonstrations. In practice, the main Alevi federation, the AABF (Federation of Alevi Communities of Germany), has presented a mainly cultural version of Aleviness since 1993. According to its 1998 programme, its main purpose is to "preserve and contribute to the development of the cultural identity and the religious or philosophical values of Alevis living in Europe". It also aims to "meet the cultural and social needs of Alevis" and commits itself to "the transmission of Alevi culture and teachings to Alevi schoolchildren". ${ }^{23}$ Most Alevi organisations in Germany consider Aleviness to be a 'culture' based on democracy, humanitarianism and gender equality.

As in contemporary Turkey, Alevi organisations have become the main loci and institutions of Aleviness in Europe. They have been trying to revive, develop and transmit Alevi practices, sometimes from scratch, thereby transforming and reinventing most of them. In particular, Alevi associations have revitalised the main Alevi ceremony, the cem. However, these new, public ceremonies - like those held by most Alevi organisations in Turkey - are

${ }^{23}$ AABF, Avrupa Alevi Birlikleri Federasyonu Programı (Cologne: AABF, 1998), article 2, § 6. 
quite different from traditional cems. While the traditional ceremonies were limited to a specific and closed community linked to a specific dede, the contemporary cems are in part directed outwards, and address an imagined global Alevi community. Their length and composition has also changed considerably. ${ }^{24}$ Many Alevis criticise these new ceremonies because they perceive them as 'performances', void of spirituality and sacral character. Alevi organisations have also been developing and teaching Alevi practices originally linked to rituals, such as playing the $s a z$ - an Anatolian instrument used in Alevi music among others and dancing the ritual semah. These practices have become symbols of Alevi identity, and are especially appreciated by the youth. Finally, Alevi associations have been organising cultural activities, such as festivals, commemorations and concerts. These events draw much public attention, and many more participants than religious ceremonies.

\subsection{Claims and conflicts}

Furthermore, Alevist organisations have, like their Turkish counterparts, been voicing demands for the recognition of Aleviness. However, in the course of the movement's development, various groups -identifiable to some extent with organisations - have emerged with diverse, or even conflicting representations of Aleviness and claims for recognition. One of the most bitterly discussed points is the relationship between Aleviness and Islam: is Aleviness 'true Islam', a specific interpretation of Islam, or a religion outside Islam -is it, for example, the real religion of Turks, or of Kurds? This issue partly overlaps with the question of whether Aleviness is a religion or not. For some activists, it is a political philosophy of liberation, resistance and democracy, while for yet another group, Aleviness is mainly a

\footnotetext{
${ }^{24}$ On ritual changes in Western Europe, see Langer, Robert, "Alevitische Rituale”, in M.Sökefeld (ed.), Aleviten in Deutschland: Identitätsprozesse einer Religionsgemeinschaft in der Diaspora (Bielefeld: Transkript, 2008), pp.65-107. For a comparison with the transformation of rituals in Turkey, see Massicard, L'autre Turquie, pp.151-159, 197-201.
} 
culture, a way of life characterised by critical-mindedness. These conflicts are also about political questions; for example, should Aleviness be integrated into Turkish institutions or not? Each group bases its perspective on reconstructions of Alevi history: for example, those who consider Aleviness a revolutionary movement emphasise social uprisings - styled 'Alevi rebellions' - against the Selcuk and Ottoman dynasties, and criticise any attempt to integrate Aleviness into Turkish institutions. It is not our aim here to describe this diversity of positions. ${ }^{25}$ Suffice it to say that the lack of consensus, regarding not only the nature of Aleviness, but also the level at which that identity should be defined (religious, social, political or cultural), is a striking feature of contemporary Alevism. Even after twenty years of activism, the debate over the definition of Alevi identity is not settled, making Alevism a very competitive and conflicted movement. This ongoing struggle over meaning reflects competing representations of Alevi claims.

In Western Europe, the power balance between different organisations and interpretations is slightly different from that in Turkey. The most important Alevi federation in Germany is the AABF. ${ }^{26}$ It is made up of more than 100 local associations and has published its own journal, Alevilerin Sesi, since 1992. Since 1993, the AABF has been headed by former leftist activists who espouse a cultural representation of Aleviness, distancing themselves from, or even opposing, the Turkish state. However, as a large federation comprising local organisations whose views range across the whole range of Alevi positions, the AABF has never issued any formal statement on the relationship between Aleviness and Islam, or on the controversial issue of the display of Turkish flags by the organisations.

\footnotetext{
${ }^{25}$ On this topic, see Vorhoff, Karin, Zwischen Glaube, Nation und neuer Gemeinschaft: Alevitische Identität in der Türkei der Gegenwart (Berlin: Klaus Schwarz, 1995); Massicard, Elise, L'autre Turquie, pp.89-109. ${ }^{26}$ Similarly, the most important federations in other European countries are those that are in close relationship with AABF.
} 
Other umbrella organisations exist in Germany, but none of them is as important as the AABF. One is the Federation of Kurdistan Alevis (Federasyona Elewiên Kurdistanî), created in 1994, and renamed the Democratic Alevi Federation (Demokratik Alevi Federasyonu) in 2002. Being closely related to the PKK, it claims that Aleviness is a Kurdish phenomenon, and that Alevi and Kurdish issues are related. It includes about twenty local Kurdish Alevi associations in Germany and, since 1994, has published a journal, Zülfikâr, renamed Semah in 2002. Another organisation active at the German federal level since 1997 is the CEM (Cumhuriyetçi Eğitim ve Kültür Merkezi) foundation, the overseas representative body of a Turkish organisation with the same name. Unlike the AABF and the Federation of Kurdistan Alevis, it is not an umbrella organization, although several local associations are closely related to it. The CEM stresses both the Islamic and the Turkish nature of Aleviness. Being quite close to the Turkish institutions, it seeks representation for Alevis within the Directorate of Religious Affairs (Diyanet), which is responsible for the official regulation of religion in Turkey, or the establishment of a similar state body for Alevis. However, this foundation could never become as significant in Germany as it is in Turkey, since its aims are hardly relevant to migrant Alevis. Similarly, the Europe Ehl-i Beyt Federation (Avrupa Ehl-i Beyt Federasyonu, ABAF) is linked to the Turkish Ehl-i Beyt foundation, and claims that Aleviness is a religious phenomenon close to Shi'a Islam, but it is hardly active in Germany. Finally, the Alevi Academy is an organization of a different kind; it mainly publishes booklets and organises courses for Alevi dedes. Cooperation between these organisations at the federal level is rare.

The situation is different at the local level, however. Many local organisations remain independent of the federations mentioned above, and not all federations are represented in every city, although the AABF has a presence almost everywhere. Thus, in many German 
cities, one may find several Alevi organisations (including village, regional, or neighbourhood associations) with different orientations, depending which are the main groups that have settled through chain migration. This often results in competition or conflicts between organisations, ${ }^{27}$ but cooperation at the local level does nevertheless take place - for example, in connection with the organisation of local events and the use of community centres. Thus, observers are confronted with a complex and geographically diverse landscape of associations. ${ }^{28}$

Beyond the institutional level, what are the perceptions of Alevis living in Western Europe? The proportion of Alevis who are members of Alevi organisations is quite low, ${ }^{29}$ and many Alevis are rather sceptical about them, although only limited data are available on this. Diverse views about whether Aleviness is primarily culture or religion, and about its relationship to Islam, are represented among Alevis, even among members of one and the same association. What is certain is that the relevance of Alevi identity to Alevis themselves has increased with the revival. In Germany, many parents have not taught or transmitted Alevi religious values to their children, so, for the second generation of migrant Alevis, religious norms and values are not very important. The identity dimension seems to be more relevant to them, and it is only rarely linked to religious practice. Nevertheless, many second-generation migrants consider Aleviness a belief within Islam (and therefore it remains for them a religious identity), even if they do not practice. ${ }^{30}$ It seems that there is a strong reluctance to

\footnotetext{
${ }^{27}$ For an account of the internal conflicts of the association in Narbonne (Southern France), see Fliche, Odyssées turques, pp.122f.

${ }^{28}$ Massicard, Elise, "Le poids du local dans les configurations associatives des alévis en Europe", in A.Guillou, M.Wadbled and S.De Tapia (eds), Migrations turques dans un monde globalisé: Le poids du local (Rennes: Presses Universitaires de Rennes, 2007), pp.57-68.

${ }^{29}$ Observers estimate that about 25,000 Alevis in Germany (i.e. roughly 5\%) are members of Alevi organisations. One should also take in account multipliers such as family. Sökefeld, "Einleitung: Aleviten in Deutschland", p.32.

${ }^{30}$ Taşçı, Hülya, "Die zweite Generation Alevitinnen und Alevitenzwischen religiösen Auflösungstendanzen undsprachlichen Differenzierungsprozessen”, in M.Sökefeld (ed.), Aleviten in Deutschland: Identitätsprozesse einer Religionsgemeinschaft in der Diaspora (Bielefeld: Transkript, 2008), p. 133-154 (141-144).
} 
deny any link to Islam, even if the idea that Aleviness is the true Islam remains a minority opinion. In Switzerland, however, it seems that the most common view expressed in public is that Aleviness is a religion for itself, independent from Islam ${ }^{31}$.

Does the Alevist movement in Western Europe have specific features distinct from the movement in Turkey? First, in Europe there is a dominant organisation, the AABF and its allied organisations, which is not the case in Turkey. ${ }^{32}$ Second, in Europe there is a more oppositional stance to the Turkish government, probably due both to weaker political restrictions as compared with Turkey, and to the influence of former leftist activists in many organisations. As a consequence, some radical trends that are underground or very marginal in Turkey seem to be stronger in Europe. One of them is Kırmanç Nationalism, a movement formed in the early 1980s struggling for an independent, Alevi, Zazaki-speaking nation. ${ }^{33}$ Similarly, Kurdish nationalist Alevi groups that are prohibited in Turkey have become more formalised in Europe, and some radical leftist groups have appeared in European cities, especially after the Gazi event in 1995. The extreme left-wing Turkish organization, the Revolutionary People's Liberation Party-Front (Devrimci Halk Kurtuluş Partisi-Cephe, DHKP-C) has formed an Alevi group in Germany called Al-Genç (Al[evi] Youth), which has issued an occasional journal called Kerbela since 1996, and has tried, without much success, to gain a foothold in some Alevi organisations. ${ }^{34}$ These endeavours are quite insignificant in the context of the overall Alevi movement as a whole. More significant characteristics of the movement in Europe, however, are: first, that its claims are addressed to Europeans who have

\footnotetext{
${ }^{31}$ Beyeler, Sarah and Virginia Suter Reich, "Inkorporation von zugewanderten Religionsgemeinschaften in der Schweiz am Beispiel der Aleviten und der Ahmadiyya", Schweizerische Zeitschrift für Religion und Kulturgeschichte, vol.102 (2008), pp.233-259 (243).

${ }^{32}$ More on this point in Massicard, L'autre Turquie, pp.286f.

${ }^{33}$ Kehl-Bodrogi, Krisztina, “'Wir sind ein Volk!' Identitätspolitiken unter den Zaza (Türkei) in der europäischen Diaspora”, Sociologus, vol.48, no.1 (1998), pp.111-135 (127).

${ }^{34}$ Kaya, "Multicultural clientelism", pp.38-40.
} 
no prejudice against Alevis (as well as, less significantly, to Sunni migrants), and, second, that the opportunities for recognition are different.

\section{DIVERSE IDENTITY STRATEGIES ACROSS EUROPE: GERMAN ALEVISM'S SHIFT TOWARDS}

\section{RELIGION}

In their countries of settlement, Alevist organisations campaign for Aleviness: in particular, they have made efforts to engage in intercultural projects and interreligious dialogue, and worked for the construction of community centres or cem houses, the introduction of Alevi religious instruction at schools, political representation, etc. They have done so at various institutional levels: municipalities, federal states, federal governments, and Europe. Interestingly, their recognition strategies are very diverse in the different places where they have settled, and are strongly linked to the institutional opportunities for integration or recognition.

The most striking example of this phenomenon is the shift towards a more religious interpretation of Alevism in Germany. ${ }^{35}$ Over the past few years, increasing numbers of Alevist organisations - primarily those affiliated with the $\mathrm{AABF}$ - have come to stress the religious dimension, adopt more religious names and regard their premises as places of worship. For the first time, two Alevi places of worship have recently been built. ${ }^{36}$ This is remarkable because, until recently, most Alevist organisations in Germany, including the overwhelming majority of those affiliated to the AABF, had expressed their distinctiveness mostly in political or cultural terms, had a generally secular attitude and remained largely indifferent to

\footnotetext{
${ }^{35}$ This is studied in more detail in Massicard, Elise, "Alevist movements at home and abroad: mobilization spaces and disjunction", New Perspectives on Turkey, vols 28-29 (Spring-Fall 2003), pp.163-187.

${ }^{36}$ In Berlin, several Alevi organisations have jointly opened a place of worship in a former church; in Augsburg, an Alevi organisation has built a new cemevi.
} 
religious issues. In Germany, there was a stronger tendency than in Turkey to situate and reimagine Aleviness outside Islam and to understate its religious dimension. The predominant view was that Aleviness is a culture based on democracy and humanism. ${ }^{37}$ Only a few Alevist organisations in Germany had had a clearly religious orientation, and most of them were not affiliated to the AABF.

Given these circumstances, how can this shift towards a more religious interpretation be explained? In Germany, state and religion cooperate and so religion is a legal category of recognition. This is particularly the case with regard to educational issues, as religion is taught in public schools. The realm of religion is therefore especially significant for the recognition of migrant groups and so the main goal for religious groups looking for official recognition is to obtain one of the existing legal statuses. The highest status is 'public law corporation' (Körperschaft des öffentlichen Rechts), but the conditions required for this status are quite difficult to meet: stability, sustainability, a clear organisational structure, and a certain number of members. The status of 'religious community' is more advantageous than that of a mere association: a religious community cannot be easily disbanded and enjoys the right to provide religious teaching in public schools.

However, until recently, Alevists neglected this possibility of religious recognition, since they did not know about it and did not appreciate the opportunities it offered. This was, first, because no migrant group had ever been granted any of these statuses and, second, because the context in which the Alevist movement started was influenced by multiculturalism, and the issue of immigration was treated mainly in terms of cultural difference. Only in the late 1990s, in accordance with 'global' trends, was attention drawn to

\footnotetext{
${ }^{37}$ On these religious reconstructions see Massicard, L'autre Turquie, pp.150-160.
} 
'fundamentalism' among the Muslim youth, and the religious dimension of migration came to the fore.

\subsection{The legal recognition of religious difference in Berlin}

What made Alevists become aware of the opportunity for religious recognition? In 2000, an administrative court granted a Sunni organisation, the Islamic Federation of Berlin (IFB), the status of a religious community. A few weeks later, Berlin's biggest Alevist organisation, the Anatolian Alevis' Cultural Centre (AAKM, Anadolu Alevileri Kültür Merkezi, which is affiliated to the AABF), suddenly seeing this opportunity, asked for the same status. Until then, the AAKM, like the AABF, had called for Aleviness to be taught in schools, but in a non-confessional manner: they preferred the inclusion of Aleviness in non-confessional, interfaith religious education classes, because they considered this model appropriate to the values of tolerance and openness emphasised by Alevis. ${ }^{38}$ However, as soon as the right to teach was given to a Sunni organisation, the AAKM applied for the establishment of a parallel course, thus moving away from a generalist and universalist stance to a particularist position.

Because of the tradition of parity between the Protestant and Catholic Christian churches, the German state is bound to adopt a neutral position regarding all religions and denominations and must guarantee the equal treatment of all religious communities. The recognition of one Muslim religious community would not, therefore, imply that it was the sole representative of Islam, but on the contrary would open the way for the recognition of other Muslim groups; German institutions, unlike the Turkish state, have no difficulty in appreciating and accepting the Sunni/Alevi difference. Becoming aware of this opportunity,

\footnotetext{
${ }^{38}$ The first time Aleviness was taught in Germany was when Alevi themes were included in 'religious instruction for all' in Hamburg public schools in 1998.
} 
activists began to posit Aleviness as a religion in need of protection and the exercise of equal rights with Sunni Islam.

Only a few months later, the AAKM was granted the status of a religious community, implicitly as part of Islam. Interestingly, the AAKM obtained this status much more quickly and easily than the IFB, whose first application dated back to 1980. How can the difference between the treatment of the IFB's and AAKM's applications by the Berlin local authorities be explained? It seems strange, because the IFB was much more active on the issue and mobilised far stronger support than did the AAKM. Moreover, the AAKM had no better claim than the IFB to having met the legal conditions for obtaining the status of religious community, and the reasons put forward for denying the status to the IFB for twenty years could easily have been used to reject the AAKM's application. The first reason was the lack of a single interlocutor representing all Muslims and of a united Muslim position. Similarly, although the AAKM is the dominant Alevi organisation, it in no way represents all Berlin Alevis, among whom divergent orientations and theological views coexist; indeed the AAKM is opposed by some organisations with which it could not reach an agreement to make a joint request for recognition, ${ }^{39}$ and it is very questionable that even AAKM members hold a shared world view. The second reason for delaying acceptance of the IFB's application had been that the internal organisation of Muslim worship is not based on a church-like hierarchy, but the same is also true of Alevi worship; the role of the dedes, the traditional religious leaders, is unclear and conflicted, due both to the lack of an overall hierarchical structure among them, and to the breakdown of traditional religious institutions.

The last legal criterion for obtaining the status of religious community is conformity with the constitution - a point on which Sunni Muslims are usually thought suspect. However,

\footnotetext{
${ }^{39}$ For an overview of the Alevi associational landscape in Berlin, see Massicard, L'autre Turquie, pp. 269-274.
} 
this is more a political issue than a purely legal one. In Germany, as in most West European countries, Islam has a very negative public image, as do Turkish migrants. Islam is often equated with reluctance to integrate, backwardness, intolerance, gender inequality, 'issues' such as the veil, and, since the late 1990s, even fundamentalism and violence. Therefore, the recognition of the IFB, an organisation that was, moreover, criticised for its supposed links with Turkish Islamist parties, was very controversial. From this perspective, the recognition of an Alevi association provided a kind of counterweight to a religion and an organisation that were perceived negatively. Indeed, the manner in which the AAKM presented itself to the German public is significant, and reflects the Alevis' strategies for self-representation.

By asserting their difference from other Turkish migrants, Alevis distanced themselves from a stigmatised Islam. Many Alevis actually agree with the widespread discourse on Islam as a threat and even contribute to spreading the stereotype of a 'fundamentalist danger'. In contrast, they depict themselves as more modern and open-minded than other Turkish migrants.

They point to what they see as their more democratic, tolerant, and progressive stance. While steadfast in their Aleviness, they identify with and admire many aspects of West German society that the Sunnis interpret as threatening. Modeling themselves on certain German, Western modes, they pride themselves on how modern they are, as opposed to the 'backward' Sunnis. They point to the 'marked' village clothing many Sunni women wear, such as the flowing şalvar pants and headscarves. ${ }^{40}$

\footnotetext{
${ }^{40}$ Mandel, Ruth, "Turkish headscarves and the 'foreigner problem': constructing difference through emblems of identity”, New German Critique, vol.46 (Winter 1989), pp.27-46 (42-43).
} 
The assertions that Alevi women do not wear headscarves, that Aleviness promotes gender equality and that it permits alcohol consumption are emphasised and presented as a significant indication that Alevis have no problems with integration in European societies. The emphasis on the Alevi/Sunni difference therefore leads to an assertion of compatibility or even similarity between Aleviness and European culture, ${ }^{41}$ so that Alevis present themselves in public as sharing the essential values of their host societies, and even as embodying what are considered 'universal' values, such as modernity, humanitarianism, tolerance, human rights, enlightenment, freedom and democracy, and as rejecting fanaticism, fundamentalism, racism, terrorism and proselytism. ${ }^{42}$ This is also the case in France, where the Alevis present themselves as defenders of laïcité (secularism) and thus claim to support the principles of the host society. ${ }^{43}$ Thus, the Alevis' position relative to that of Sunnis has undergone an important improvement in European settlement societies as compared with Turkey:

Migrant Alevis have in many ways successfully reversed their hierarchically subordinate position to the Sunni Turks (...) Thus, by adhering to practices and symbols meaningful to Germans, Alevis are then thought of and labeled by Germans as being 'better integrated' than Sunnis (...) The Alevis might be slightly less marginal (i.e., more integrated) than Sunnis with respect to mainstream German society. As a

\footnotetext{
${ }^{41}$ Sökefeld, Struggling for Recognition, pp.183ff.

42 This seems to be congruent with the assertions that Alevis try to integrate in the host society and are satisfied with their lives in Germany, and that many Alevis have applied for German citizenship. Shankland and Çetin, "Aleviten in Deutschland", p.224; Sökefeld, Struggling for Recognition, pp.196-203.

${ }^{43}$ Fliche, Benoit, "Contextes d'implantation et reconfigurations sociales à Narbonne et Ankara", in A.Guillou, M.Wadbled and S.De Tapia (eds), Migrations turques dans un monde globalisé: Le poids du local (Rennes: Presses Universitaires de Rennes, 2007), pp.141-154 (145).
} 
consequence of their greater acceptance of German ways and people, they become more accepted by Germans than are many Sunnis. ${ }^{44}$

This helps the Alevis to appear legitimate and maintain good links with the public in European countries. Interestingly, this representation has been widely adopted by German politicians, who are aware of the differences between Sunnis and Alevis. They often use the Alevis as an example of Turks who 'integrate successfully'. ${ }^{45}$ During the Alevi cultural night organised by the AAKM in 1996, referred to above, the Social Democrat mayor of the district of Wedding characterized Aleviness as a political counterweight to Islamic radicalism. $\mathrm{He}$ even called upon the German people to stand with the Alevis against the challenge of "radical Islam from within" looming over Europe and Germany. ${ }^{46}$ This representation is also to be found in the press. The daily Die Tageszeitung speaks of "liberal Alevis" in contrast to the IFB, and defines them as "non-dogmatic Muslims". ${ }^{47}$ Thus the German media and public opinion have developed a favourable perception of Aleviness, and public discourses prevalent in Western Europe provide important symbolical resources for Alevis. Beyond the issue of legal status, the differentiated treatment of denominations seems to be clearly related to the political issues related to the presence of Islam in Germany.

\subsection{The religious transformation of German Aleviness}

As the requirements for religious recognition in Germany are basically derived from Christian traditions, adjustment to them has resulted in important transformations and the reformatting

\footnotetext{
${ }^{44}$ Mandel, "Turkish headscarves”, pp.42-43.

${ }^{45}$ Mandel, "Shifting centres and emergent identities", p.156.

${ }^{46}$ Kaya, "Multicultural clientelism", pp.42-43

47 “Aleviten in Berlin: liberale und undogmatische Muslime” Die Tageszeitung, 10 April 2000, p. 19 [no author].
} 
of Aleviness on the Christian model. Among the legal preconditions for the status of religious community was a clear self-positioning of the AABF as a religious body, so in 2002 the AABF changed its internal organisation and adopted new by-laws under which the AABF changed its German name to Alevitische Gemeinde Deutschland (Alevi Community of Germany) - the term Gemeinde having a clear religious connotation - instead of the previous Föderation der Alevitengemeinden (Federation of Alevi Communities) - the term 'Federation' being a relic of the period of big political organisations. Simultaneously, the second paragraph of the new by-laws explicitly designated the AABF as a "religious community in the sense of the basic Law of the Federal Republic of Germany" instead of the previous “democratic mass organisation" reminiscent of left-wing discourse. Moreover, in order to qualify as a religious community, the AABF had to prove the existence of a clearly identifiable organisational structure and to furnish proof of a binding religious authority. This was problematic, because the dedes - considered the 'clergy' of Aleviness - had long been marginalised in most Alevi organisations, and there was no formalised relationship between the AABF and the dedes' council (dedeler kurulu) as no statutes specified the competences of this body. In 2003, the AABF thus formally redefined the role of the religious dignitaries, though it is still questionable whether the new dedes' council carries the authority to issue binding doctrinal statements, since decision-making remains in the hands of the board. It is also questionable whether the associations linked to the AABF have been able to integrate the dedes in a generally accepted way, since their role, of variable importance, is still a strongly debated issue. ${ }^{48}$

Moreover, the $\mathrm{AABF}$ had to furnish proof of a consensus on dogma and belief, a quite difficult task where Alevis are concerned. Traditionally, the teachings were handed down orally within different religious lineages. Due to the often divergent oral traditions, it would

\footnotetext{
${ }^{48}$ On this point see Sökefeld, Struggling for Recognition, pp.104, 164ff.
} 
be an exaggeration to speak of a single and coherent Alevi belief system, but that is exactly what was required. In 1999, the AABF founded a 'Commission for Religious Instruction', which pursues the aim of developing a 'teachable' religion so as to meet the legal requirements. In order to succeed in the negotiations over religious instruction, this commission initiated the drawing up of a syllabus, which has broken new ground, since it is the first organised effort to write down, systematise and unify dogmas and beliefs and formalise learning within Aleviness. ${ }^{49}$ In the syllabus, specific features differentiating Aleviness from orthodox Islam are stressed, and Aleviness is presented as a coherent system of belief on the model of Christianity. For example, although traditionally there were no specific Alevi religious buildings in which ceremonies were conducted, ${ }^{50}$ the syllabus presents the cemevi (cem = house) as the Alevi place of worship, like the church or the mosque. $^{51}$

Could these recent developments towards a more religious view of Aleviness be a consequence of sociological developments? The fact that the first migrant generation has now reached retirement age and may be more aware of religious needs may well be a factor. Have the pensioners marginalised the most influential generation of Alevist leaders, who are mainly secular, former leftists, often political refugees? This is unlikely. In fact, those who are leading this shift towards a more religious interpretation of Alevism are not the first generation of now elderly migrant workers, but the former leftists themselves, who have publicly tempered their former secularism, or even atheism. On the whole, this increased emphasis on religion is not so much due to a resurgence of religiosity but rather appears to be a strategic response to

\footnotetext{
49 There have been other attempts, mostly in Turkey, but they were not successful, due to the numerous differences and the lack of opportunity to formalise such efforts. See Massicard, L'autre Turquie, pp.164-165.

${ }^{50}$ In ordinary villages, ceremonies usually took place in the largest room of a house. Specifically religious buildings existed only in places of pilgrimage and, since the 1990s, in the premises of Alevist organisations. Nowadays, some are also being constructed in Alevi villages.

${ }^{51}$ AABF, Lehrplanentwurf für den alevitischen Religionsunterricht (Cologne: AABF, 2002), pp.32-33.
} 
changed public discourses and an adjustment to prevailing institutional requirements for recognition. This new framework seems to be goal-oriented and deliberate. A significant indication for this strategic interpretation is that the AAKM is not the most religious Alevist organisation in Berlin; rather, it is the biggest and the most orientated towards German institutions and public sphere.

\section{VARIOUS LEVELS OF ACTION AND THE DIFFICULT TRANSNATIONALISATION OF IDENTITY}

\section{STRATEGIES}

This development raises the interesting question of the multiplicity of levels of action. In Germany, states (Länder) are responsible for matters related to worship and education. For this reason, the recognition of religious groups is a Land matter. Each state offers different legal opportunities for religious education, and the groups granted the status of religious community differ from one state to the other. The recognition of the AAKM occurred in the Land of Berlin. Seeking to benefit from these local dynamics, the AABF tried to extend this recognition to the national level. A few weeks after the recognition of the AAKM, the AABF made similar applications on behalf of affiliated organisations in the biggest states where Alevis are settled. These states then decided to give a joint answer to this request. They commissioned two expert reports and eventually the application was accepted ${ }^{52}$. The issue of recognition, initially local, has been taken to the national level both by activists and by institutions.

\footnotetext{
52 The lessons began in 2002 in Berlin, in 2006 in Baden-Württemberg, in 2008 in North Rhine-Westphalia and Bavaria, and in 2009 in Hesse. In each state, a few hundred children attend these lessons. It would be interesting to analyse how the recently established courses in Aleviness in state schools in Germany have influenced Alevis' representation of Aleviness.
} 
More generally however, this adaptation to local contexts challenges the unity of Alevism across Europe, because this 'religious turn-around' has not been on the agenda in most other European countries. In Denmark, for example, the main Alevi federation was recognised as a separate religious community (i.e. distinct from Islam) in 2007 and has thus been granted rights, e.g. to conduct official marriages, to obtain work permits for 'clergy' brought from abroad, and to acquire Alevi spaces in cemeteries. In contrast, in republican France, activists of the main Alevist federation, the Federation of Alevi Communities of France (Fédération des Unions des Alévis en France, $\mathrm{FUAF}^{53}$ ) - most of whom are secular, mainly former left-wing militants, i.e. 'sociologically' similar to the AABF in Germany have not adopted this religious tone. The FUAF's statutes and aims do not refer to Aleviness as a religion, but to Alevi philosophy and culture. ${ }^{54}$ Similarly, the second article of its by-laws defines the FUAF as a "democratic mass organisation" aimed at "protecting the philosophical and cultural values of the Alevi community in France and Europe and at developing its cultures and customs", very similar to the statutes of the AABF before its religious turnaround. This is best explained by the fact that France adheres strictly to the principle of laïcité (secularism), which implies a clear-cut separation of religion and state, and severely restricts opportunities of the recognition of religious groups. There, a framework that stresses the high value given by the Alevis to human rights is politically and strategically more relevant.

In Switzerland, the situation is different again. Most migrants arrived in the 1980s, many of them as political exiles, either following the 1980 coup or because of the hostilities between the PKK and the Turkish army. ${ }^{55}$ Most of the fifteen Alevi associations in Switzerland define themselves as "democratic mass organisations" or "cultural, progressive and humanist-thinking" organizations, and only one defines itself explicitly as a religious

\footnotetext{
${ }^{53}$ Founded in 1998, it comprises about 35 organisations.

${ }^{54}$ FUAF, Les objectifs de la fédération des unions des alévis en France (Paris: FUAF, 2000).

${ }^{55}$ Beyeler and Suter Reich, "Inkorporation von zugewanderten Religionsgemeinschaften", p.239.
} 
community. ${ }^{56}$ However, the Swiss political system has a triple structure articulated at federal, cantonal and communal levels. This opens up locally diverse opportunities for institutional integration, which influence the Alevis' strategies for recognition. In Basel, for example, Alevi associations seek official recognition as a separate and independent religious community, distinct from Islam. They started to articulate their demands in the religious arena at a time when Basel's cantonal administration was working on re-defining the relationship between state and religion, because migrant religious groups - especially the numerous Muslims - had not been dealt with on equal terms with established religious communities. The aim was, therefore, to grant them almost the same rights. When the administration started to investigate the Muslims' calls for recognition, it established contact with the main Muslim umbrella association, which it soon came to consider as representative of Islam and as a negotiating partner. Since this association was Sunni, Alevists feared they might automatically be included under its umbrella, so they started to present themselves in public as a separate religious group, independent from Islam. In order to validate their views, they stressed the fact that the Qur'an and mosques are not important to Alevis, and Alevis are now perceived by Basel public opinion as a distinct religious community, and are co-opted into processes of political consultation and considered as partners in interreligious dialogue. So far, however, neither the Sunnis nor the Alevis have been granted formal, legal recognition, because of their lack of a centralised organisational structure ${ }^{57}$ Interestingly, in other Swiss cantons, where there is no possibility of formal recognition for migrant religious groups, Alevist organisations present a much less religious orientation. For example, in Winterthur, in the canton of Zürich, where such regulations are not on the agenda, the Alevist association

\footnotetext{
${ }^{56}$ Beyeler and Suter Reich, "Inkorporation von zugewanderten Religionsgemeinschaften”, pp.239-241.

${ }^{57}$ Beyeler and Suter Reich, "Inkorporation von zugewanderten Religionsgemeinschaften”, pp.249f.
} 
does not call for on religious recognition, but campaigns for its members' political rights. ${ }^{58}$ Thus, the same kind of diversity observed between recognition strategies in Germany and France can be observed in Swiss cantons.

These divergent developments indicate that the discourses and recognition strategies of Alevist movements in settlement countries are shaped less by their imported traditions or the 'nature' of Aleviness than by the institutional and discursive contexts within which they are embedded. The crucial role played in the migrants' claim-making process by the institutional and political framework in the country of settlement has been analysed elsewhere. Spatially bounded institutional contexts and political agendas provide access to different discursive and institutional resources and frame the discourse and strategies of Alevist claim-making. Alevism, being active in various political spaces, is confronted with a variety of political opportunities. The adaptation of Alevist organisations to their settlement context, in terms of strategies and discourses, challenges the unity of the movement across Europe and the links between these political spaces will now be addressed.

\subsection{Organisations at the transnational level}

This issue has become even more crucial since Alevi organisations in Europe have given greater consideration to becoming more oriented towards their settlement countries in recent years. They had initially been committed to 'homeland politics', i.e. their priority was to support the Alevist struggle in Turkey. This homeland orientation tended to be the rule among activists from Turkey in migration. ${ }^{59}$ In the 1990 s, the main aim of the AABF and other Alevi federations was to criticise the discriminatory policies of the Turkish state towards Alevis.

\footnotetext{
${ }^{58}$ Suter Reich, Virginia, "Anerkennungspraktiken alevitischer Gemeinschaften im Kontext der jüngsten baselstädtischen Verfassungsreform”, unpublished manuscript, 2009.

${ }^{59}$ Østergaard-Nielsen, Eva, Transnational Politics: Turks and Kurds in Germany (London: Routledge, 2003), pp.46f.
} 
Since the late 1990s, however, along with the turn towards migrant politics and institutional integration strategies, the increased orientation of the Alevist organisations towards their settlement countries has been on the agenda. The AABF has started various Europe-oriented projects, such as an information campaign about the new German citizenship law. It has also established numerous contacts with the German authorities at all levels.

How far are Alevist organisations in Europe linked to their counterparts in Turkey? Several attempts have been made to establish a transnational umbrella organisation to encompass organisations in Turkey and Europe,${ }^{60}$ but these attempts have been unsuccessful, due in part to the legal difficulties of creating a transnational federation in Turkey, and in part to political conflicts over strategy - most of them originating in Turkey. Nevertheless, there are close relationships between organisations across the Bosphorus. Even without their Turkish counterparts, the national federations in Europe (the AABF and its sister organisations) are closely linked to each other: although the German associations were the most numerous and played the leading part, the $\mathrm{AABF}$ originally also included associations from other European countries and renamed itself Avrupa Alevi Birlikleri Federasyonu (Federation of Alevi Communities in Europe) in 1994. In 1998, the name was again changed to the Federation of Alevi Communities in Germany, and the non-German associations left it to form their own national federations. Later, there were attempts to found a worldwide confederation of Alevi associations with its centre in Turkey, but the confederation could not include Turkish members because of legal difficulties. At the end of a long process, the national Alevi federations in Europe (Germany, France, Denmark, Austria, Holland, Belgium,

\footnotetext{
${ }^{60}$ The first attempt at a transnational umbrella organisation embracing almost all the existing Alevist organisations in Turkey and Europe, the Alevi-Bektaşi Temsilciler Meclisi (ABTM, Council of Alevi-Bektashi Representatives), dates back to 1994. Its chairman was the chairman of the AABF. However, it soon split because of conflicts between organisations over their stance toward the Turkish state and political strategies for the 1995 legislative elections. In 1999, a second Alevi-Bektashi Representative Assembly, comprising 31 organisations in Turkey and European countries (including the national federations of Germany, Austria, France, Switzerland, England, Holland and Australia) came into being, but it was also short-lived.
} 
Switzerland and some associations from Sweden and Norway) formed a transnational umbrella organisation, the Confederation of Alevi Communities in Europe (Avrupa Alevi Birlikleri Konfederasyonu, AABK) in 2002, which was legally registered in 2006.

This confederation, however, is not very 'binding'. Its programme and statutes are quite broad, being an interesting mixture of former leftist discourse (stressing values such as freedom, equality, labour, secularism and democracy) and quasi-religious terms. The AABK is defined as both a democratic organisation and a "faith organisation" (inanç örgütü). It defines Aleviness as a distinct Anatolian inanç (faith), i.e. independent of Islam, and also stresses that it is, at the same time, a principle of behaviour and thought. ${ }^{61}$ The use of the term inanç is interesting, because it has a more open meaning than the word din (religion), which carries connotations of (Sunni) Islam. The AABK declares that it is working for the Alevis living in Europe to be able to live their faiths, cultures and identities. With regard to its homeoriented demands, it calls for Aleviness be legally recognised in Turkey, without defining precisely on what terms. However, it also calls for cem houses to be recognised as faith centres, that the Diyanet be disbanded, and that compulsory religious education be abolished. The non-binding character of the AABK is to be seen in the fact that the faith council of the $\mathrm{AABF}$ (the main member organisation of the AABK) disagrees with the AABK's definition of Aleviness. In 1998, the AABF defined Aleviness as a faith system with a distinct interpretation of Islam, separate from the Sunni faith. Moreover, the AABF definition includes more reference to Islam, especially to Ali and Muhammad and the AABF faith council considers the AABK to be too centred on cultural aspects, and too little on religious

\footnotetext{
${ }^{61}$ Interestingly, in previous statements the AABK had defended views of Aleviness as both an independent religious community and a part of Islam. This inconsistency shows the difficulty of maintaining a single definition of Aleviness across Europe, and probably reflects power balances and responses to changing situations.
} 
ones. The existence of a confederation is not enough for us to conclude that there is agreement across Europe over the definition of Aleviness, or that there is a united plan of action.

Beyond these institutional and discursive matters, it is more relevant to consider joint actions across national borders. Interestingly, there has been hardly any integrated Alevist action across national borders apart from the transfer of quite limited financial support from Europe to Turkey. Interestingly, the main shared activities are linked to the European Union. With the approach of the crucial 2004 European summit, which was to decide on whether to open the negotiation process with Turkey, the (not yet registered) AABK and an important Alevist organisation in Turkey embarked on a joint campaign stressing their support for Turkey's accession to the EU and launching a petition for the abolition of compulsory religious education and the recognition of Alevi places of worship in Turkey. Thus, it was Turkey's European political agenda that led to the first coordinated, trans-European campaign across bothTurkey and the various countries of settlement. This 'joint' nature of this campaign should be qualified, however, since the petition did not explicitly define the relationship of Aleviness to Islam - the AABK at the time defending the view that Aleviness was an interpretation of Islam, whereas the Turkish organisation rejected that position.

\subsection{The EU level}

Thus we see that a further policy- and claims-making level must be added to these local and national developments: the EU level, although it mostly concerns the Alevi issue in Turkey. Alevi organisations have attempted to involve EU institutions and to use Turkey's EU accession process as a lever for change in Turkey. Like most Alevis in Europe, Alevist federations favour Turkey's admission to the EU, hoping that it would facilitate the democratisation of Turkey and better rights for Alevis, and they have therefore been trying to 
add the Alevi issue to the list of matters requiring improvement as a condition for Turkey's accession to the EU.

In December 1999, at the Helsinki summit, Turkey was recognised as a candidate for membership of the EU. The conditions Turkey must fulfill in order to begin negotiations for membership are the Copenhagen criteria, including the protection of minorities. Since 2000, the Alevi issue has been mentioned in the regular reports of the European Commission on Turkey's progress towards accession. In November 2000, the first Regular Report referred to it in the following terms:

The official approach towards the Alevis seems to remain unchanged. Alevi complaints notably concern compulsory religious instruction in schools and school books, which would not reflect the Alevi identity, as well as the fact that financial support is only available for the building of Sunni mosques and religious foundations. These issues are highly sensitive; however, it should be possible to have an open debate on them ${ }^{62}$.

This statement is reiterated in almost the same words in later reports, which are critical of the absence of improvement and the lack of formal recognition of Alevis, the fact that they are not represented by the Diyanet, the fact that compulsory religious instruction in schools still fails to acknowledge the Alevi identity, and their difficulties in opening places of worship. The European Commission has thus legitimised Alevists' demands, but what is interesting is that the Commission implicitly recognises Aleviness as a religious phenomenon within Islam. Besides, these statements are found in the section concerning freedom of religion, itself

\footnotetext{
${ }^{62}$ European Commission, 2000 Regular Report from the Commission on Turkey's Progress towards Accession (Brussels: European Commission, 2000), p.18.
} 
included in the chapter on "civic and political rights", not in the chapter on "rights and protection of minorities", which deals mainly with gypsies and Kurds. The 2003 report refers to Alevis as a "non-Sunni Moslem community",63 and the 2004 report as a "non-Sunni Muslim minority". ${ }^{64}$ These definitions raised much opposition from Alevists in both Europe and Turkey. Therefore, so it is not clear how far the engagement of EU institutions with the Alevi issue is the result of the mobilisation of Alevist organisations in Europe.

\section{CONCLUSION}

Alevis have settled in many West European countries since the 1960s, and have become visible in European public spaces since the 1990s. Unlike 'mainstream' Muslims from whom they assert their difference, Alevis enjoy a relatively good image in Europe. Taking advantage from this, Alevist organisations have engaged in strategies for institutional integration and recognition in their countries of settlement. However, Aleviness remains a quite blurred and contested identity, and its religious, cultural and political dimensions are balanced differently by the various Alevist organizations, which have adapted their identity and recognition strategies to the various political contexts in which they are embedded in order to maximize their chances for recognition. Very divergent developments are observed across Europe: Aleviness has been recognised as a religious community within Islam in Germany and as a distinct religion in Denmark, and has been described as a humanist and democratic culture in other contexts, such as France. These divergent developments produce contradictions and conflicts on the transnational and even the trans-local levels. In fact, the location of organisations, the spaces in which they are active, and the goals they try to attain, may well be

\footnotetext{
${ }^{63}$ European Commission, 2003 Regular Report from the Commission on Turkey's Progress towards Accession (Brussels: European Commission, 2003), p.36.

${ }^{64}$ European Commission, 2004 Regular Report from the Commission on Turkey's Progress towards Accession (Brussels: European Commission, 2004), p.44.
} 
distinct. For example, when Alevist organisations in Western Europe lobby the European Commission, they do so mainly on the Alevi issue in Turkey. But the same organisations also work in European settlement countries for Alevi migrants, and may defend diverse claims in these various spaces. It is a fact that the $\mathrm{AABF}$ has been opportunistically presenting a more religious version of Aleviness when Germany is concerned than when Turkey is. What remains to be seen in the long run is whether the recognition categories prevalent in specific contexts will impact the representations Alevis themselves make of Aleviness, for example through the teaching of Aleviness at schools. From a marginalised and silenced phenomenon back in Anatolia, Aleviness has become a clear indicator of the lack of political unity across Europe - with or without Turkey. 